Jurnal Ekonomi Modernisasi

http://ejournal.unikama.ac.id/index.php/JEKO

JEM 12,2 (2016) 51-62

Jumal Ekonomi Modernisasi

\title{
PERAN KOMPENSASI DAN KARAKTERISTIK LEADERSHIP PADA KINERJA GURU YANG DIMEDIASI OLEH KEPUASAN KERJA
}

\author{
Mirza Dwinanda Ilmawan \\ Fakultas Ekonomi dan Bisnis Universitas Internasional Semen Indonesia \\ Jl. Veteran, Kec. Gresik, Jawa Timur \\ Noermijati \\ Fakultas Ekonomi dan Bisnis Universitas Brawijaya \\ Jl. MT. Haryono 165 Malang
}

\begin{abstract}
The objective of this research is to analyze direct and indirect effects of compensation on State Senior High School (SMA) teachers' performances in Malang City mediated by work satisfaction. This research also aims to analyze direct and indirect influence of leadership characteristics on State Senior High School (SMA) teachers' performances in Malang City mediated by work satisfaction. The population of this research is all teachers of State Senior High School (SMA) in Malang City who have got Sertifikasi Guru amounted at 460 people and the sampling technique is Proportional Random Sampling which results sample of 100 people. The primary data collecting uses questionnaires as instrument. Data analysis method using path analysis technique. This research results indicate that compensation directly influences teacher's performances. It also proves indirect influence of compensation on teachers' performances mediated by work satisfaction. Other than those, it states that leadership characteristics affects on teachers' performances directly. And leadership characteristics affects on teachers' performances mediated by work satisfaction.
\end{abstract}

Keywords: Compensation, Leadership Characteristics, Teachers' Performances, Work Satisfaction.

DOI : http://dx.doi.org/10.21067/jem.v12i2.1190

Diterima : Februari 2016; Direvisi April 2016; Diterima : Mei 2016

PENDAHULUAN

Pendidikan merupakan masalah yang penting bagi setiap bangsa yang sedang dalam tahap membangun. Upaya perbaikan di bidang pendidikan merupakan suatu keharusan untuk selalu dilaksanakan agar suatu bangsa dapat maju dan berkembang seiring dengan kemajuan ilmu pengetahuan dan teknologi.

* Corresponding Author.

E-mail: mirza.ilmawan@uisi.ac.id
Upaya yang dilaksanakan yang antara lain penyempurnaan kurikulum, peningkatan kompetensi guru melalui penataran-penataran, perbaikan sarana, perbaikan sarana-sarana pendidikan, dan lain-lain. Hal ini dilaksanakan untuk meningkatkan mutu pendidikan bangsa dan terciptanya manusia Indonesia seutuhnya.

Berdasarkan fungsi dan tujuan pendidikan nasional yang tertuang dalam Undang-undang Nomor 20 Tahun 2003 tentang Sistem Pendidikan Nasional (pasal 3). 
Pendidikan nasional berfungsi mengembangkan kemampuan dan membentuk watak serta peradaban bangsa yang bermartabat dalam rangka mencerdaskan kehidupan bangsa serta mengembangkan potensi peserta didik agar menjadi manusia yang beriman dan bertaqwa kepada Tuhan Yang Maha Esa, berakhlak mulia, sehat, berilmu, cakap, kreatif, mandiri, dan menjadi warga negara yang demokratis serta bertanggung jawab. Hal ini harus dibarengi dengan peningkatan mutu tenaga pendidik dan pendidikan dalam segi perekrutan, kompetensi, dan manejemen pengembangan sumberdaya manusianya.

Melalui Undang-Undang Nomor 14 Tahun 2005 tentang Guru dan Dosen (UUGD) yang disahkan Tanggal 30 Desember 2005 pemerintah mengupayakan peningkatan kompetensi guru melalui sertifikasi guru. Pasal yang menyatakannya adalah Pasal 8: guru wajib memiliki kualifikasi akademik, kompetensi, sertifikat pendidik, sehat jasmani dan rohani, serta memiliki kemampuan untuk mewujudkan tujuan pendidikan nasional.

"Program sertifikasi sudah dimulai sejak Tahun 2005 dan selama ini guru yang lolos proses sertifikasi melalui penilaian portofolio mendapat tunjangan satu kali gaji pokok, namun pada kenyataannya sertifikasi tersebut tidak memberikan dampak signifikan terhadap kinerja guru dalam kegiatan belajar mengajar", kata Kepala Badan Pengembangan Sumberdaya Manusia Pendidikan dan Penjaminan Mutu Pendidikan (BPSDMP dan PMP) Kemdiknas Syawal Gultom, di Jakarta, Jumat (23/09/2011).

Oleh karena itu, Kemdiknas mencari cara supaya guru bisa mengubah kinerja pasca sertifikasi dan mulai tahun depan pihaknya akan merancang peraturan menteri (permen) yang akan mengukur standar kompetensi guru. Pendataan dilakukan secara online, data dikirim berjenjang dari sekolah, dinas kabupaten/kota, Lembaga Penjaminan Mutu Pendidikan (LPMP) hingga ke Kemdiknas. "Akan diketahui, berapa bulan atau tahun tunjangannya ditunda", katanya.

Dari data dalam jaringan (online) tersebut guru dapat melihat apakah dirinya sudah memenuhi kriteria sertifikasi atau tidak. Melalui sistem komputerisasi yang ada, jelasnya, para guru itu juga akan dievalusi kinerjanya. Ada empat indikator evaluasi yakni kepribadian, pedagogik (pemahaman ilmu yang diajarkan), sosial, dan keprofesionalitasan guru. nantinya, standar kriteria sama secara nasional namun skor di masing-masing daerah berbeda.

Sosialisasi mengenai hal ini sudah dilakukan sejak diterbitkannya Permenag PAN dan RB no 16/2009 tentang Penilaian Kinerja Guru. Sambil berjalan sosialisasi, ujarnya Kemdiknas juga akan menyiapkan modul agar kompetensi mereka dapat mencapai indeks nilai yang disyaratkan (Burhani, 2011).

\section{TINJAUAN PUSTAKA}

Syawal mengatakan hasil penelitian yang dilakukan Kementerian Pendidikan Nasional (Kemdiknas), pascaprogram pemberian sertifikasi guru melalui penilaian portofolio sejak tahun 2005 lalu tidak memberi dampak besar terhadap perubahan kultur di sekolah menjadi lebih baik, kinerja guru dalam mengajar di kelas, dan peningkatan kemampuan siswa.

Contoh dari hasil penelitian yang dilakukan oleh Wiratmadja dan Govindaraju (2008) dengan fenomena yang terjadi tersebut diatas menunjukkan adanya research gap dalam hal faktor yang mempengaruhi kinerja guru khususnya tunjangan sertifikasi guru. Ternyata kompensasi berupa tunjangan sertifikasi guru tidak selalu dapat mempengaruhi secara positif kinerja guru, tetapi ada faktor lain yang dapat mempengaruhi kinerja guru.

Pada dasarnya kompensasi berhubungan dengan tingkat kepuasan seseorang dalam bekerja, namun kepuasan kerja sulit ditaksir. Adanya dugaan ketidaksesuaian dalam memberikan upah maupun gaji merupakan salah satu indikator ketidakpuasan seseorang terhadap kompensasi yang diterimanya dan pada akhirnya dapat menimbulkan perselisihan dan semangat kerja yang rendah dari seseorang itu (Strauss et al, 1985). Oleh karena itu prinsipprinsip dalam pemberian kompensasi bagi pengembangan individu yang bisa merangsang 
mereka agar lebih meningkatkan kontribusinya bagi organisasi harus diperhatikan. Dengan tercapainya kepuasan seseorang terhadap kompensasi tersebut akan menciptakan kepuasan kerjanya. Ketidakpuasan seseorang terhadap kompensasi yang diterimanya akan menimbulkan perilaku negatif orang tersebut terhadap organisasi dan dampak akhirnya dapat menurunkan kinerjanya (Mondy et al, 1993).

Abu Ajip dalam Azura (2004) menyatakan bahwa setiap organisasi mempunyai suatu tujuan yang perlu dicapai. Oleh karena itu individu yang terlibat dalam organisasi seharusnya memperoleh kepuasan kerja yang optimal. Ini dapat menjamin peningkatan moral, dan prestasi kerja ke arah peningkatan produktivitas yang tinggi.

Ketercapaian tujuan pendidikan sangat bergantung pada kecakapan dan kebijaksanaan kepemimpinan kepala sekolah yang merupakan salah satu pemimpin pendidikan. Karena kepala sekolah merupakan seorang pejabat yang profesional dalam organisasi sekolah yang bertugas mengatur semua sumber organisasi dan bekerja sama dengan guru-guru dalam mendidik siswa untuk mencapai tujuan pendidikan. Dengan keprofesionalan kepala sekolah ini pengembangan profesionalisme tenaga kependidikan mudah dilakukan karena sesuai dengan fungsinya, kepala sekolah memahami kebutuhan sekolah yang ia pimpin sehingga kompetensi guru tidak hanya berhenti pada kompetensi yang ia miliki sebelumnya, melainkan bertambah dan berkembang dengan baik sehingga profesionalisme guru akan terwujud.

Kepala sekolah merupakan salah satu komponen pendidikan yang paling berperan dalam meningkatkan kualitas pendidikan. Sebagaimana dikemukakan dalam Pasal 12 ayat 1 PP 28 Tahun 1990 bahwa: "Kepala sekolah bertanggung jawab atas penyelenggaraan kegiatan pendidikan, administrasi sekolah, pembinaan tenaga kependidikan lainnya, dan pendayagunaan serta pemeliharaan sarana dan prasarana".

Kepemimpinan yang baik tentunya sangat berdampak pada tercapai tidaknya tujuan organisasi karena pemimpin memiliki pengaruh terhadap kinerja yang dipimpinnya. Kemampuan untuk mempengaruhi suatu kelompok untuk mencapai tujuan merupakan bagian dari kepemimpinan. Konsep kepemimpinan erat sekali hubungannya dengan konsep kekuasaan. Dengan kekuasaan pemimpin memperoleh alat untuk mempengaruhi perilaku para pengikutnya. Penelitian Wiratmadja dan Govindaraju (2008) menunjukkan bahwa kepuasan kerja dosen di organisasi pendidikan tinggi, terutama di kasus universitas, akan membaik jika pemimpin organisasi bertindak baik dan benar dalam menerapkan gaya kepemimpinan transformasional.

\section{METODE PENELITIAN}

Jenis penelitian ini merupakan penelitian survei, yaitu penelitian yang mengambil sampel dari suatu populasi dan menggunakan kuesioner sebagai instrumen pengumpulan data yang utama. Dengan demikian, penelitian ini dikategorikan sebagai explanatory research, yaitu penelitian yang menjelaskan hubungan kausal antara variabel-variabel penelitian melalui pengujian hipotesis (Singarimbun dan Effendi, 2006). Lingkungan penelitiannya field, yaitu penelitian lapangan yang bertujuan untuk mendapatkan data empiris untuk pengujian hipotesis. Pengujian hipotesis menggunakan skala likert.

Penelitian ini dilakukan di SMA Negeri Kota Malang. Kota Malang dipilih sebagai lokasi penelitian karena merupakan kota nomor dua terbesar di Jawa timur yang juga dikenal sebagai kota pendidikan. Obyek dan subyek penelitian ini ditetapkan secara purposif yaitu seluruh guru SMA Negeri di Kota Malang yang sudah lolos proses Sertifikasi Guru yang berjumlah 460 guru. Dari populasi sejumlah 460 guru, penelitian ini menggunakan jumlah guru yang dijadikan sampel adalah sebanyak 100 guru tersertifikasi.

Populasi penelitian ini mempunyai unsur yang tidak homogen, yaitu terbagi dalam beberapa departemen atau unit kerja, atau dengan kata lain terbagi dalam sub populasi, dimana setiap departemen atau unit kerja memiliki jumlah guru yang berbeda-beda. Oleh 
karena itu teknik pengambilan sampelnya menggunakan Proportional Random Sampling, yaitu teknik pengambilan sampel secara acak dengan jumlah yang proporsional untuk masingmasing sub populasi, dengan demikian masingmasing sampel untuk setiap departemen diambil secara proporsional sesuai dengan ukuran populasinya (Sugiyono, 2004; Sekaran, 2006).

\section{HASIL DAN PEMBAHASAN Karakteristik Responden}

Berikut ini dijelaskan beberapa gambaran data mengenai karakteristik biografi dari responden yang telah diteliti sebagai berikut:

Dari hasil penelitian yang dilakukan, menunjukkan bahwa pekerjaan sebagai guru pada kenyataannya membutuhkan keuletan dan kesabaran lebih untuk mendidik anak didik dengan karakter yang berbeda-beda dari tiap individunya. Pekerjaan sebagai guru tersebut nyatanya lebih disukai oleh perempuan. Hal ini dibuktikan bahwa responden yang berjenis kelamin laki-laki hanya sebanyak 41 orang dan responden yang berjenis kelamin perempuan lebih banyak yakni 59 orang.

Distribusi Responden Menurut Usia menunjukkan bahwa sebagian besar guru hampir menginjak usia pensiun. Data ini juga mengungkapkan fakta bahwa masih kurangnya jumlah guru baru atau guru muda di Kota Malang. Sebaran responden paling banyak terdapat pada rentang usia 51 sampai usia 55 tahun.

Distribusi responden menurut masa kerja menggambarkan sebaran responden paling banyak terdapat pada rentang masa kerja antara 26 - 30 tahun yaitu sejumlah 33 responden. Data menggambarkan bahwa responden yang diteliti memiliki tingkat kesetiaan terhadap pekerjaan mereka yang cukup tinggi yang dapat dibuktikan dari lama masa kerja dengan keinginan yang kuat untuk tetap menjadi guru hingga saat ini.

Data yang diperoleh menggambarkan kondisi di lapangan bahwa guru yang sudah tersertifikasi cukup memadai, dibuktikan bahwa hanya terdapat 1 guru atau responden dalam penelitian ini dari tingkat pendidikan D-3, S-1 sebanyak 76 guru, bahkan terdapat lulusan dari jenjang S-2 yaitu sebanyak 13 guru.

\section{Deskripsi Variabel Penelitian}

Dalam memberikan interpretasi nilai ratarata atau pemberian makna penilaian secara empiris variabel penelitian ini mengadopsi dasar interpretasi yang digunakan dalam penelitian Noermijati (2008) dengan rata-rata pembobotan atau nilai skor jawaban responden yang diperoleh diklasifikasikan ke dalam rentang skala kategori nilai yang disajikan pada Tabel 1.

\section{Tabel 1}

Dasar interpretasi skor indikator dalam variabel penelitian

\begin{tabular}{ccc}
\hline No. & $\begin{array}{c}\text { Nilai rata- } \\
\text { rata skor } \\
\text { jawaban }\end{array}$ & $\begin{array}{c}\text { Makna/ } \\
\text { interpretasi }\end{array}$ \\
\hline 1. & $1.0-1.8$ & Sangat Rendah \\
2. & $>1.8-2.6$ & Rendah \\
3. & $>2.6-3.4$ & Cukup tinggi \\
4. & $>3.4-4.2$ & Tinggi \\
5. & $>4.2-5.0$ & Sangat tinggi \\
\hline
\end{tabular}

Sumber: Noermijati (2008)

\section{Kompensasi $\left(\mathrm{X}_{\mathbf{1}}\right)$}

Nilai mean sebesar 3.66 menunjukkan bahwa tingkat kompensasi yang diberikan kepada guru berada pada kategori tinggi. Untuk nilai rata-rata setiap indikator dari variabel kompensasi, skor tertinggi adalah pada indikator penyelesaian pekerjaan bahwa sekolah memberikan kesempatan untuk menyelesaikan tugas pekerjaan yang dibebankan agar tepat waktu dengan nilai rata-rata indikator sebesar 3.75. Namun untuk nilai rata-rata tertinggi dari setiap item, skor tertinggi dicapai oleh salah satu item dari indikator kompensasi langsung. Item ini berkenaan dengan besarnya gaji apakah sudah sesuai dengan tugas dan tanggung jawab sebagai guru. Responden dengan yakin menganggap bahwa gaji mereka telah sesuai 
dengan tugas dan tanggung jawab mereka sebagai guru yang dapat dibuktikan dengan nilai rata-rata 3.85. Nilai rata-rata sebesar 3.85 termasuk dalam kategori penilaian yang tinggi.

\section{Karakteristik Kepemimpinan $\left(\mathbf{X}_{2}\right)$}

Diketahui bahwa nilai rata-rata dari variabel karakteristik kepemimpinan sebesar 3.98 dan termasuk dalam kategori tinggi. Hal ini menggambarkan bahwa responden berpendapat bahwa karakteristik kepemimpinan dari kepala sekolah sudah sesuai dengan keinginan atau kebutuhan organisasi. Sedangkan nilai rata-rata tertinggi dari setiap indikator dihasilkan dari indikator memberdayakan pihak lain yang memiliki nilai rata-rata sebesar 4.41. Dapat dilihat bahwa responden sangat memperhatikan item karakter kepemimpinan dari apakah Kepala Sekolah sudah dapat mempercayakan kekuasaan kepada guru sesuai aturan untuk menyelesaikan tugas-tugas sekolah. Hal yang menjadi inti dari pernyataan tersebut adalah guru merasa yakin menganggap bahwa Kepala Sekolah memiliki rasa kepercayaan terhadap kekuasaan yang telah diberikan kepada guru untuk menyelesaikan tugas-tugas sekolah.

\section{Kepuasan Kerja (Z)}

Nilai rata-rata variabel kepuasan kerja sebesar 3.85 dapat dikategorikan tinggi. Responden sangat menyukai pekerjaan yang dilakukan saat ini dengan nilai rata-rata indikator tertinggi sebesar 3.99 yang termasuk dalam kategori tinggi. Hal ini sejalan dengan apa yang telah dibahas pada penjelasan tentang karakteristik responden yang membuktikan bahwa sebagian besar responden telah bekerja dengan rentang masa kerja antara 26 - 30 tahun yakni sebanyak 33 responden. Mereka menyukai pekerjaan yang dilakukan saat ini dan berkeinginan kuat untuk tetap menjadi guru hingga sekarang.

\section{Kinerja Guru (Y)}

Nilai rata-rata variabel kinerja guru yang tergolong tinggi yaitu sebesar 3.96. Nilai ratarata indikator tertinggi diperoleh dari indikator kompetensi kepribadian sebesar 4.05. Untuk nilai item rata-rata tertinggi pun didapat dari indikator kompetensi kepribadian yaitu item Y $_{1.2 .3}$ dimana guru mampu menunjukkan rasa tanggung jawab sebagai guru sebesar 4.18.

\section{Hasil Validitas dan Reliabilitas Instrumen Penelitian \\ Uji Validitas Instrumen}

Hasil uji validitas dari seluruh instrumen memiliki koefisien korelasi $\geq 0.30$ sehingga dapat disimpulkan bahwa semua item pernyataan yang digunakan sebagai instrumen dalam penelitian ini adalah valid dan layak untuk dianalisis lebih lanjut.

\section{Uji Reliabilitas Instrumen (Test of Reliability)}

Hasil olah data menunjukkan nilai Alpha Cronbach's dari seluruh indikator variabel yang dijadikan sebagain intrumen dalam penelitian ini adalah masih berada diatas cut of value $\geq 0.6$ berarti semua item pernyataan yang dijadikan instrumen dapat dipercaya keandalanya. Persyaratan nilai alpha cronbach's telah terpenuhi oleh semua indikator variabel dengan nilai berada diatas 0.6 atau $60 \%$ sehingga instrumen layak untuk dianalisis lebih lanjut.

\section{Perhitungan Koefisien Jalur}

Tujuan perhitungan koefisien jalur untuk mengetahui pengaruh sesama variabel laten yang dirancang dalam penelitian ini. Variabel laten yang dibangun dalam penelitian ini yaitu: Kompensasi, Karakteristik Kepemimpinan, Kepuasan Kerja, dan Kinerja Guru. Selanjutnya keempat variabel laten dalam penelitian ini dihubungkan sehingga menghasilkan tujuh jalur dalam model penelitian ini yaitu lima pengaruh langsung dan dua pengaruh tidak langsung. 


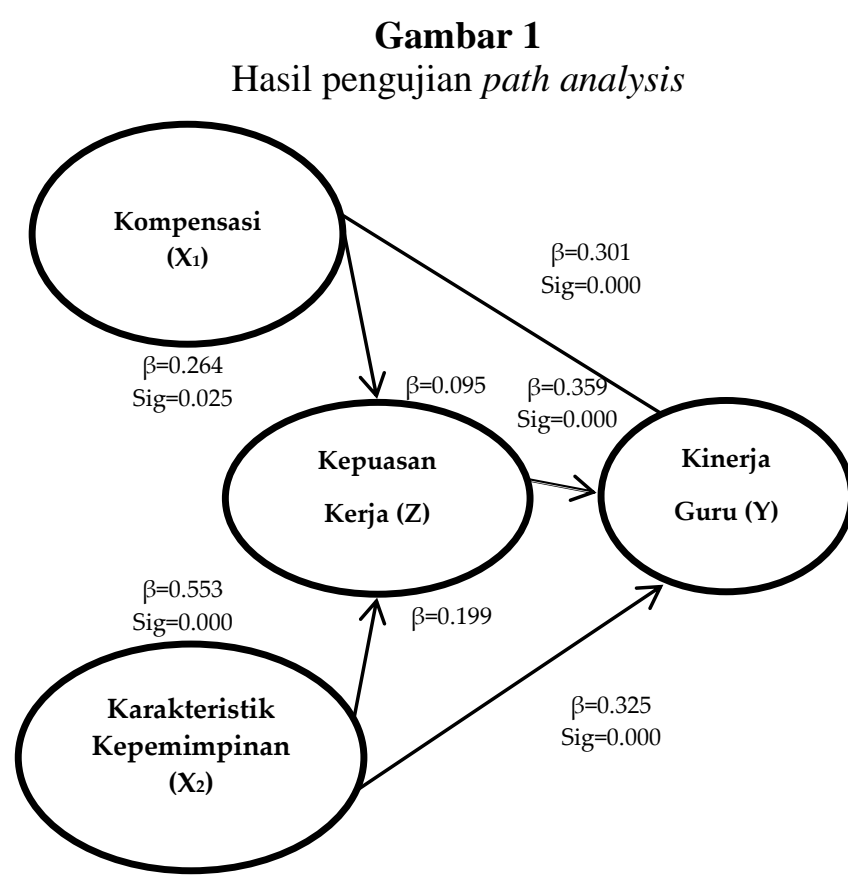

Lima pengaruh langsung yang dimaksud adalah:

1. Pengaruh kompensasi terhadap kepuasan kerja.

2. Pengaruh karakteristik kepemimpinan terhadap kepuasan kerja.

3. Pengaruh kompensasi terhadap kinerja guru.

4. Pengaruh karakteristik kepemimpinan terhadap kinerja guru.

5. Pengaruh kepuasan kerja terhadap kinerja guru.

Berdasarkan data dalam Gambar 5.1. di atas menunjukkan bahwa kelima pengaruh langsung di atas positif dan signifikan. Artinya: (a) peningkatan Kompensasi searah dan signifikan terhadap peningkatan Kepuasan Kerja dan Kinerja Guru, (b) Peningkatan Karakteristik Kepemimpinan searah dan signifikan terhadap peningkatan Kepuasan Kerja dan Kinerja Guru, (c) peningkatan Kepuasan Kerja searah dan signifikan terhadap peningkatan Kinerja Guru.

Dua pengaruh tidak langsung yang dimaksud dalam penelitian ini adalah:

1. Pengaruh kompensasi terhadap kinerja guru melalui kepuasan kerja.
2. Pengaruh Karakteristik Kepemimpinan terhadap kinerja guru melalui kepuasan kerja.

Data dalam Gambar 1 menunjukkan bahwa variabel Kepuasan Kerja menjembatani pengaruh langsung antara Kompensasi terhadap Kinerja Guru dan pengaruh antara Karakteristik Kepemimpinan terhadap Kinerja Guru. Artinya peranan Kepuasan Kerja dalam memperlemah pengaruh Kompensasi terhadap Kinerja Guru sebesar 0.095 jauh lebih kecil daripada pengaruh langsung yakni sebesar 0.301. Demikian pula peranan Kepuasan Kerja dalam memperlemah pengaruh Karakteristik kepemimpinan terhadap Kinerja Guru yaitu sebesar 0,199 lebih kecil dibanding pengaruh langsung sebesar 0,325 .

\section{Pemeriksaan Validitas Model}

Selain itu terdapat dua indikator validitas model di dalam analisis jalur, yaitu koefisien determinasi total dan trimming theory.

\section{Koefisien Determinasi Total}

Total keragaman data yang dapat dijelaskan oleh model diukur dengan:

$$
\mathrm{R}_{\mathrm{m}}^{2}=1-\mathrm{P}_{\mathrm{e} 1}^{2} \mathrm{P}_{\mathrm{e} 2 \ldots .}^{2} \mathrm{P}_{\mathrm{ep} n}^{2}
$$

Interpretasi terhadap $\mathrm{R}^{2}{ }_{\mathrm{m}}$ sama dengan interpretasi koefisien determinasi $\left(\mathrm{R}^{2}\right)$ pada analisis regresi. Model dikatakan valid jika memiliki presisi dan akurasi tinggi. Ukuran akurasi model adalah koefisien determinasi $\left(\mathrm{R}^{2}\right)$ dengan nilai berkisar dari 0 sampai dengan 1. Berdasarkan Gambar 1 diperoleh koefisien determinasi total:

$$
\mathrm{Pe}_{1}=\sqrt{1-R_{1}^{2}} \quad \mathrm{Pe}_{2}=\sqrt{1-R_{2}^{2}}
$$

$$
\mathrm{Pe}_{1}=\sqrt{1-0.613} \quad \mathrm{Pe}_{2}=\sqrt{1-0.823}
$$

$\mathrm{Pe}_{1}=0.622 \quad \mathrm{Pe}_{2}=0.421$

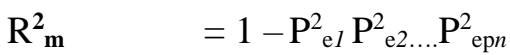

$\mathrm{R}_{\mathrm{m}}^{2} \quad=1-(0.622)^{2}(0.421)^{2}$ 


$$
\begin{aligned}
& =1-(0.387)(0.177) \\
& =0.931 \\
& =93.1 \%
\end{aligned}
$$

Nilai $\quad \mathrm{R}_{\mathbf{m}}{ }_{\mathrm{m}}$ tersebut menunjukkan informasi yang terkandung dalam data $93.51 \%$ dapat dijelaskan oleh model. Sedangkan sisanya $6.49 \%$ dijelaskan oleh variabel lain yang belum terdapat dalam model dan error. Koefisisn $\mathrm{R}^{2}{ }_{\mathrm{m}}$ sebesar $93.51 \%$ dikategorikan sangat tinggi, sehingga model dikatakan sangat baik. Model dengan koefisien determinasi total yang besar menunjukkan model yang semakin baik.

Berdasarkan triming theory dengan menggunakan $\alpha=0.05$, maka jalur-jalur yang nonsignifikan dibuang, sehingga diperoleh model yang didukung oleh data empirik. Pada penelitian ini semua lintasan atau hubungan yang dibentuk berpengaruh signifikan, sehingga diperoleh model baik yang sesuai dengan teori dan penelitian terdahulu.

\section{Uji Hipotesis Penelitian}

Taraf signifikasi estimasi parameter ditentukan dengan nilai probabilitas dengan taraf signifikasi sebesar $\alpha=0,05$ atau $95 \%$. Dasar pengambilan keputusan untuk pengujian hipotesis digunakan nilai signifikan ( $p$-value) dengan kriteria $p$-value $<0.05$, maka $\mathrm{H}_{0}$ ditolak dan $\mathrm{H}_{1}$ diterima, artinya terdapat pengaruh yang signifikan antara variabel eksogen dengan variabel endogen. Jika $p$-value $>0.05$, maka $\mathrm{H}_{0}$ diterima dan $\mathrm{H}_{1}$ ditolak, artinya variabel eksogen tidak berpengaruh signifikan terhadap variabel endogen.

\section{Pembahasan Hasil Penelitian}

Berdasarkan hasil uji hipotesis dapat diketahui seluruh variabel independen berpengaruh positif dan signifikan terhadap variabel dependen. Dapat diketahui bahwa variabel karakteristik kepemimpinan memiliki peran yang lebih baik daripada kompensasi untuk meningkatkan kepuasan kerja dari guru dimana kepuasan kerja dalam penelitian ini berperan sebagai variabel intervening. Variabel kepuasan kerja merupakan variabel paling berpengaruh terhadap variabel kinerja guru. Berikut ini disajikan pembahasan hasil penelitian yang didasarkan pada hasil pengujian hipotesis yang dikemukakan dalam model penelitian dan dukungan teori dan hasil-hasil penelitian terdahulu.

\section{Pengaruh Kompensasi Terhadap Kepuasan Kerja}

Hasil penelitian ini menunjukkan bahwa kompensasi berpengaruh signifikan dan positif terhadap kepuasan kerja. Hal tersebut berarti peningkatan kompensasi yang diberikan kepada guru maka akan berdampak secara langsung meningkatkan kepuasan kerja dari para guru. Hal ini sesuai dengan pernyataan Handoko (1998) yang menyatakan bahwa kepuasan kerja pegawai (guru) didapatkan melalui kompensasi. Responden bersikap positif terhadap pekerjaan maupun lingkungan pekerjaan yang mereka hadapi. Artinya mereka merasa puas terhadap pekerjaan mereka termasuk kompensasi yang mereka peroleh. Seperti penelitian terdahulu yang dilakukan oleh Christien et al (2006) telah membuktikan bahwa kompensasi memberikan pengaruh signifikan terhadap kepuasan kerja pun sejalan dengan penelitian ini.

Hasil analisis deskriptif menunjukkan bahwa tingkat kompensasi yang diberikan kepada guru berada pada kategori tinggi yang ditunjukan dengan nilai mean atau nilai rata-rata variabel sebesar 3.66. Untuk nilai rata-rata setiap indikator dari variabel kompensasi, skor tertinggi adalah pada indikator penyelesaian pekerjaan dimana sekolah memberikan kesempatan untuk menyelesaikan tugas pekerjaan yang dibebankan agar tepat waktu dengan nilai rata-rata 3.75. Namun untuk nilai rata-rata tertinggi dari setiap item, skor tertinggi dicapai oleh salah satu item dari indikator kompensasi langsung. Item ini berkenaan dengan besarnya gaji apakah sudah sesuai dengan tugas dan tanggung jawab sebagai guru. Responden dengan yakin menganggap bahwa gaji mereka telah sesuai dengan tugas dan tanggung jawab mereka sebagai guru yang dapat dibuktikan dengan nilai rata-rata 3.85. Hal tersebut dibuktikan oleh sikap responden yang sangat menyukai pekerjaan mereka yang 
dilakukan saat ini dengan nilai rata-rata tertinggi dibanding indikator lain yaitu sebesar 3.99 yang termasuk dalam kategori tinggi.

Berdasarkan hasil analisis deskriptif tersebut dapat dilihat bahwa responden menganggap bahwa semakin besar kompensasi yang diberikan kepada mereka (guru) maka akan berbanding lurus dengan kepuasan kerja dari para guru yang positif dan signifikan, sehingga dapat dikatakan semakin besar kompensasi yang diberikan kepada guru maka akan dapat meningkatkan kepuasan kerja dari para guru tersebut.

\section{Pengaruh Karakteristik Kepemimpinan terhadap Kepuasan kerja}

Hasil penelitian ini menunjukkan bahwa karakteristik kepemimpinan berpengaruh signifikan dan positif terhadap kepuasan kerja. Hal tersebut berarti semakin baik karakteristik kepemimpinan maka akan berdampak secara langsung meningkatkan kepuasan kerja dari para guru.

Dalam penelitian ini, karakteristik kepemimpinan dinilai dari beberapa indikator seperti sikap menghargai orang lain, mengembangkan orang lain, berkomitmen membangun komunitas, memberdayakan pihak lain, rasa percaya, dan rendah hati. Dari hasil analisis deskriptif data dapat diketahui bahwa nilai rata-rata tertinggi dari setiap indikator dihasilkan dari indikator memberdayakan pihak lain yang memiliki nilai rata-rata sebesar 4.41. Responden sangat puas terhadap item karakter kepemimpinan dari Kepala Sekolah yang dapat mempercayakan kekuasaan yang diberikan kepada guru sesuai aturan untuk menyelesaikan tugas-tugas sekolah.

Hasil penelitian ini mendukung hasil penelitian Ruvendi (2005) yang meneliti tentang gaya kepemimpinan pengaruhnya terhadap kepuasan kerja karyawan di Balai Besar Industri Hasil Pertanian Bogor. Hasil dari penelitian tersebut menyatakan bahwa terdapat hubungan dan pengaruh signifikan antara variabel gaya kepemimpinan dengan kepuasan kerja pegawai. Bukan hanya itu, penelitian ini juga mendukung penelitian Wiratmadja dan Govindaraju (2008) yang membuktikan bahwa gaya kepemimpinan transformasional memiliki pengaruh pengaruh positif signifikan terhadap kepuasan kerja dosen universitas, baik secara parsial maupun simultan. Rofhanda (2008) juga menyatakan dalam temuannya bahwa semakin baik kepemimpinan maka akan berpengaruh terhadap peningkatan kinerja. Didapatkan hubungan positif yang kuat terungkap antara kepemimpinan kepala sekolah terhadap kepuasan kerja guru dan kepemimpinan pelayanan adalah prediktor signifikan terhadap kepuasan kerja guru ditemukan dalam hasil penelitian Cerit (2009).

\section{Pengaruh Kompensasi terhadap Kinerja Guru}

Hasil penelitian ini menunjukkan bahwa kompensasi berpengaruh signifikan dan positif terhadap kinerja guru. Hal tersebut berarti peningkatan besaran kompensasi yang diberikan kepada guru maka akan berdampak secara langsung meningkatkan kinerja guru. Responden merasa kompensasi adalah segala sesuatu yang mereka terima sebagai kontribusi balas jasa atas kerja mereka dan merupakan salah satu upaya untuk meningkatkan kinerja mereka.

Hasil analisis deskriptif untuk nilai ratarata setiap indikator dari variabel kompensasi, skor tertinggi adalah pada indikator penyelesaian pekerjaan dimana sekolah memberikan kesempatan untuk menyelesaikan tugas pekerjaan yang dibebankan agar tepat waktu dengan nilai rata-rata 3.75 . Hal ini ditunjukkan oleh rasa tanggung jawab mereka yang menunjukkan nilai rata-rata variabel kinerja guru yang tergolong tinggi yaitu sebesar 3.96. Nilai rata-rata tertinggi diperoleh dari indikator kompetensi kepribadian $\left(\mathrm{Y}_{2}\right)$ sebesar 4.05. Untuk nilai item rata-rata tertinggi pun didapat dari indikator kompetensi kepribadian yaitu item $\mathrm{Y}_{2.3}$ dimana guru mampu menunjukkan rasa tanggung jawab sebagai guru sebesar 4.18.

Skor tertinggi dicapai oleh salah satu item dari indikator kompensasi langsung. Item ini berkenaan dengan besarnya gaji apakah sudah 
sesuai dengan tugas dan tanggung jawab sebagai guru. Responden dengan yakin menganggap bahwa gaji mereka telah sesuai dengan tugas dan tanggung jawab mereka sebagai guru yang dapat dibuktikan dengan nilai rata-rata 3.85 .

Hasil dalam penelitian ini mendukung Wiratmadja dan Govindaraju (2008) yang menemukan bahwa sistem kompensasi berpengaruh positif dan signifikan secara langsung maupun tidak langsung pada kinerja dosen. Adapun penelitian Cahyanto (2009) juga mengemukakan bahwa terdapat pengaruh langsung dan signifikan antara variabel kompensasi finansial terhadap kinerja dosen. Artinya apabila kompensasi finansial yang diberikan oleh pihak yayasan diberikan secara layak dan cukup maka kinerja dosen tetap pada Yayasan Universitas Nusantara PGRI Kediri akan meningkat.

\section{Pengaruh Karakteristik Kepemimpinan terhadap Kinerja Guru}

Hasil penelitian ini menunjukkan bahwa karakteristik kepemimpinan berpengaruh signifikan dan positif terhadap kinerja guru. Hal tersebut berarti semakin baik karakteristik kepemimpinan dari kepala sekolah maka akan berdampak secara langsung meningkatkan kinerja guru.

Hal ini sesuai dengan penelitian terdahulu oleh Fernandez (2003) dalam hasil penelitiannya yang menemukan bahwa pemimpin memiliki dampak positif terhadap kinerja pada level kesulitan tugas yang lebih tinggi dan kontribusinya terhadap kinerja juga meningkat ketika tugas semakin sulit. Dalam hal ini adanya gaya kepemimpinan yang secara aktif mempromosikan perubahan yang dapat memiliki dampak positif terhadap kinerja. Wiratmadja dan Govindaraju (2008) juga menyatakan bahwa kepemimpinan transformasional berpengaruh positif dan signifikan secara langsung pada kinerja dosen.

Responden menilai karakteristik kepemimpinan dalam kategori tinggi dengan nilai rata-rata 3.98. Dapat diketahui juga bahwa nilai rata-rata tertinggi dari setiap indikator dihasilkan dari indikator memberdayakan pihak lain yang memiliki nilai rata-rata sebesar 4.41. Dapat dilihat bahwa responden sangat memperhatikan item karakter kepemimpinan dari apakah Kepala Sekolah sudah dapat mempercayakan kekuasaan kepada guru sesuai aturan untuk menyelesaikan tugas-tugas sekolah. Dengan mempercayakan kekuasaan kepada guru dalam menyelesaikan tugas-tugas sekolah, guru telah mampu menunjukkan rasa tanggung jawab yang telah diamanatkan kepada mereka. Hal ini tercermin dari skor item nilai rata-rata tertinggi yang didapat dari indikator kompetensi kepribadian yaitu item dimana guru mampu menunjukkan rasa tanggung jawab sebagai guru sebesar 4.18 dan termasuk dalam kategori tinggi.

\section{Pengaruh Kepuasan Kerja terhadap Kinerja Guru}

Hasil penelitian ini menunjukkan bahwa kepuasan kerja berpengaruh signifikan dan positif terhadap kinerja guru. Hal tersebut berarti semakin baik kepuasan kerja yang dirasakan oleh guru maka akan berdampak secara langsung meningkatkan kinerja guru. Nilai rata-rata variabel kepuasan kerja sebesar 3.85 dapat dikategorikan tinggi. Responden sangat menyukai pekerjaan yang dilakukan saat ini dengan nilai rata-rata tertinggi dibanding indikator lain yaitu sebesar 3.99 dan termasuk dalam kategori tinggi. Hal tersebut menunjang kinerja guru yang terbukti dari nilai item ratarata tertinggi yang didapat dari indikator kompetensi kepribadian yaitu item dimana guru mampu menunjukkan rasa tanggung jawab sebagai guru sebesar 4.18 dan termasuk dalam kategori tinggi.

Hasi penelitian ini mendukung Wiratmadja dan Govindaraju (2008) dalam penelitiannya yang menemukan bahwa kepuasan kerja berpengaruh positif dan signifikan terhadap kinerja dosen. Hal ini menunjukkan bahwa kepuasan kerja memainkan peran penting dalam organisasi pendidikan tinggi, terutama kasus di universitas, karena bisa meningkatkan kinerja dosen. 
Pengaruh Kompensasi terhadap Kinerja Guru dimediasi Kepuasan Kerja

Hasil penelitian ini menunjukkan adanya pengaruh positif dan signifikan tidak langsung antara kompensasi terhadap kinerja guru dimediasi kepuasan kerja. Hal tersebut berarti semakin baik kompensasi yang diberikan kepada guru maka akan dapat meningkatkan kepuasan kerja dari guru yang pada akhirnya akan berdampak secara tidak langsung meningkatkan kinerja guru. Penelitian ini mendukung hasil dari Wiratmadja dan Govindaraju (2008) yang menemukan bahwa sistem kompensasi berpengaruh positif dan signifikan secara langsung maupun tidak langsung pada kinerja dosen. Penelitian ini menunjukkan bahwa nilai koefisien jalur pengaruh tidak langsung kompensasi terhadap kinerja guru yang dimediasi oleh kepuasan kerja sebesar 0.095 lebih kecil daripada nilai koefisien jalur dari pengaruh langsung antara kompensasi terhadap kinerja guru sebesar 0.301 .

\section{Pengaruh Karakteristik Kepemimpinan terhadap Kinerja Guru melalui Kepuasan Kerja}

Hasil penelitian ini menunjukkan adanya pengaruh positif dan signifikan tidak langsung antara karakteristik kepemimpinan terhadap kinerja guru yang dimediasi oleh kepuasan kerja. Hal tersebut berarti semakin baik karakteristik kepemimpinan yang dimiliki oleh kepala sekolah maka akan meningkatkan kepuasan kerja dari guru yang pada akhirnya akan berdampak secara tidak langsung meningkatkan kinerja guru. Penelitian ini mendukung hasil dari Wiratmadja dan Govindaraju (2008) yang menemukan bahwa kepemimpinan transformasional berpengaruh positif dan signifikan secara langsung maupun tidak langsung pada kinerja dosen. Hal ini menunjukkan bahwa kepuasan kerja dosen di organisasi pendidikan tinggi, terutama di kasus universitas, akan membaik jika pemimpin organisasi bertindak baik dan benar dalam menerapkan gaya kepemimpinan transformasional. Penelitian ini menunjukkan bahwa nilai koefisien jalur pengaruh tidak langsung antara karakteristik kepemimpinan terhadap kinerja guru yang dimediasi oleh kepuasan kerja sebesar 0.199 lebih kecil daripada nilai koefisien jalur dari pengaruh langsung antara karakteristik kepemimpinan terhadap kinerja guru sebesar 0.325 .

\section{Keterbatasan Penelitian}

Beberapa keterbatasan dalam penelitian ini adalah sebagai berikut:

Penelitian ini hanya meneliti hubungan antara variabel kompensasi, karakteristik kepemimpinan, kepuasan kerja, dan kinerja guru.

Penelitian ini hanya dilakukan pada guru di SMA Negeri di Kota Malang sehingga tidak dapat digeneralisasikan terhadap seluruh guru di Kota Malang maupun seluruh Indonesia.

\section{SIMPULAN}

Penerapan kompensasi pada guru yang bercirikan: kompensasi langsung, kompensasi tidak langsung, kompensasi bukan uang, penyelesaian pekerjaan, pencapaian prestasi, dan otonomi tugas terbukti mampu mendukung peningkatan kepuasan kerja dari para guru.

Penerapan karakteristik kepemimpinan dari kepala sekolah yang bercirikan: menghargai orang lain, mengembangkan orang lain, membangun komunitas, memperlihatkan autentisitas, memberikan kepemimpinan, memberdayakan pihak lain, rasa percaya, dan rendah hati terbukti mampu meningkatkan kepuasan kerja dari para guru.

Penerapan kompensasi pada guru yang bercirikan: kompensasi langsung, kompensasi tidak langsung, kompensasi bukan uang, penyelesaian pekerjaan, pencapaian prestasi, dan otonomi tugas terbukti mampu mendukung peningkatan kinerja guru.

Penerapan karakteristik kepemimpinan dari kepala sekolah yang bercirikan: menghargai orang lain, mengembangkan orang lain, membangun komunitas, memperlihatkan autentisitas, memberikan kepemimpinan, memberdayakan pihak lain, rasa percaya, dan 
rendah hati terbukti mampu meningkatkan kinerja guru.

Semakin tinggi kepuasan kerja dari para guru yang dicirikan: kebanggaan terhadap pekerjaan; ketika ada peluang/tawaran yang lebih baik, tidak akan berpindah kerja; ketika mencapai prestasi yang tinggi, tetap tidak ingin berpindah kerja di tempat lain; sangat menyukai pekerjaan yang dilakukan saat ini; dan secara keseluruhan, merasa puas terhadap pekerjaan terbukti mampu meningkatkan kinerja guru.

Penerapan kompensasi pada guru yang bercirikan: kompensasi langsung, kompensasi tidak langsung, kompensasi bukan uang, penyelesaian pekerjaan, pencapaian prestasi, dan otonomi tugas melalui kepuasan kerja yang meliputi: kebanggaan terhadap pekerjaan; ketika ada peluang/tawaran yang lebih baik, tidak akan berpindah kerja; ketika mencapai prestasi yang tinggi, tetap tidak ingin berpindah kerja di tempat lain; sangat menyukai pekerjaan yang dilakukan saat ini; dan secara keseluruhan merasa puas terhadap pekerjaan, terbukti mampu meningkatkan kinerja guru.

Penerapan karakteristik kepemimpinan dari kepala sekolah yang bercirikan: menghargai orang lain, mengembangkan orang lain, membangun komunitas, memperlihatkan autentisitas, memberikan kepemimpinan, memberdayakan pihak lain, rasa percaya, dan rendah hati melalui kepuasan kerja yang meliputi: kebanggaan terhadap pekerjaan; ketika ada peluang/tawaran yang lebih baik, tidak akan berpindah kerja; ketika mencapai prestasi yang tinggi, tetap tidak ingin berpindah kerja di tempat lain; sangat menyukai pekerjaan yang dilakukan saat ini; dan secara keseluruhan merasa puas terhadap pekerjaan, terbukti mampu meningkatkan kinerja guru.

\section{SARAN}

Berdasarkan temuan-temuan penelitian ini hendaknya kepala sekolah meningkatkan kompensasi terkait dengan otonomi tugas. Otonomi tugas yang dimaksud adalah kepala sekolah memberikan kesempatan bagi guru untuk ikut serta dalam proses pengambilan keputusan.
Kepala sekolah perlu dapat mengambil inisiatif dalam bekerja. Apabila kepala sekolah mampu mengambil inisiatif dalam bekerja, ini akan menjadi panutan/contoh bagi guru dalam meningkatkan kinerja mereka. Namun apabila kepala sekolah tidak mampu mengambil inisiatif dalam bekerja maka guru pun akan enggan untuk meningkatkan kinerja mereka.

Dalam upaya peningkatan kinerja guru, maka pemerintah maupun kepala sekolah perlu memberikan program berkala mengenai pengembangan terhadap penguasaan teori belajar oleh guru. Program ini dapat berupa workshop, seminar nasional, dan bahkan beasiswa untuk melanjutkan jenjang pendidikan mereka.

Saran bagi peneliti selanjutnya

Penelitian ini memberikan ruang bagi peneliti selanjutnya untuk menambahkan variabel lain seperti komitmen, fasilitas kerja, dan lain sebagainya yang berkaitan ke dalam penelitian selanjutnya.

Penelitian ini memungkinkan bagi peneliti selanjutnya untuk meneliti tidak hanya pada guru SMA Negeri di Malang tetapi bisa juga mengikutsertakan responden dari Madrasah Aliyah negeri, bahkan dapat juga memasukkan responden dari guru pengajar setingkat SMP maupun SD, sehingga hasil penelitian dapat digeneralisasikan untuk guru yang ada di Kota Malang serta penelitian selanjutnya dapat membandingkan perespsi guru baik SMA, SMP, dan SD di Kota Malang tentang kompensasi yang diperoleh.

\section{DAFTAR PUSTAKA}

Azura Binti Mohd Nor. 2004. Faktor-faktor yang Mempengaruhi Kepuasan Kerja Guru dalam Bidang Teknik dan Vokasional Berdasarkan Teori Maslow Di Sekolah Akademik Di Daerah Pasir Puteh, Kelantan. Tesis. Universiti Teknologi Malaysia.

Burhani, Ruslan. 2011. Kemdiknas Laksanakan Penilaian Kinerja Guru Tahun Depan. http://www.antaranews.com/berita/276796/ kemdiknas-laksanakan-penilaian-kinerja- 
guru-tahun-depan. Diakses pada 23/11/2011.

Cahyanto, Dwi Hari. 2009. Pengaruh Kompensasi terhadap Motivasi dan Kinerja Dosen. Tesis. Program Pascasarjana Fakultas Ekonomi Universitas Brawijaya, Malang.

Carmeli, Abraham dan Anad Freud. 2004. Work Commitment, Job Satisfaction, and Job Performance: an Empirical Investigation. International Journal of Organizational Theory and Behavior. Vol. 7 No. 3, pp: 289-309.

Cerit, Yusuf. 2009. The Effects of Servant Leadership Behaviours of School Principals on Teachers Job Satisfaction, Educational Management Administration, and Leadership. Vol. 37, No. 5, 600-623.

Christien, M., Iyer Ganesh., and David Soberman. 2006. Job Satisfaction, Job Performance, and Effort: A Reexamination Using Agency Theory. Journal of Marketing. Vol 70. 137-150.

Fernandez, Sergio. 2003. Developing and Testing an Integrative Framework of Public Sector Managerial Leadership: Evidence from the Public Education Arena. Journal of National Public Management Research, Vol. 24, pp. 1220.

Handoko, T Hani. 1998. Manajemen Personalia dan Sumberdaya Manusia. BPFE Universitas Gajah Mada, Yogyakarta.

Hasibuan, Melayu, S. P. 2007. Manajemen Sumberdaya Manusia. Haji Masagung. Jakarta.

Mondy, R. Wayne and Noe, Robert M. 1993. Human Resources Management. Allyn Bacon.

Noermijati. 2008. Aktualisasi Teori Herzberg, Suatu Kajian Terhadap Kepuasan Kerja dan Kinerja Spiritual Manajer Operasional. Disertasi. Program Pascasarjana Fakultas Ekonomi Universitas Brawijaya, Malang.

Rofhanda, Yuri, 2008, Pengaruh Kepemimpinan, Kompensasi, dan motivasi terhadap Kepuasan Kerja di Unit Kerja PT. Telkom Div. Infratel Netre Sumbagut
Medan, Tembung. Tesis. Program Pascasarjana Fakultas Ekonomi Universitas Brawijaya, Malang.

Ruvendi, Ramlan. 2005. Imbalan dan Gaya Kepemimpinan Pengaruhnya terhadap Kepuasan Kerja Karyawan, Balai Besar Industri Hasil Pertanian Bogor. Jurnal Ilmiah Binaniaga Vol. 01 No. 1.

Sekaran, Uma. 2006. Metodologi Penelitian untuk Bisnis. Penerjemah: Kwan Men Yon. Edisi 4. Buku 2. Salemba Empat, Jakarta.

Simamora, Henry. 2006. Manajemen Sumber Daya Manusia. Edisi 3. BP STIE YKPN, Yogyakarta.

Singarimbun, Masri dan Sofian Effendi. 2006. Metode Penelitian Survey. Edisi Revisi. LP3ES, Jakarta.

Strauss, George \& Savies, Leonardo. 1985. Manajemen Personalia: Segi Manusia dalam Organisasi (Edisi Terjemahan). Pustaka Binaan Pressindo, Jakarta.

Sugiyono. 2004. Metode Penelitian Bisnis. CV. Alfabeta, Bandung.

Undang-undang RI No. 20 Tahun 2003, Tentang Sistem Pendidikan Nasional. Sinar Grafika, Jakarta.

Undang-undang RI No. 14 Tahun 2005, Tentang Guru dan Dosen. Diperbanyak oleh Penerbit Citra Umbara, Bandung.

Wiratmadja, Iwan Inrawan and Rajesri Govindaraju. 2008. The Influence of Transformational Leadership Style and Compensation System on the Performance of University Lecturer, a Case at a State University in Indonesia. Proceedings of the 9th Asia Pasific Industry Engineering and Management Systems Conference, APIEMS 2008, Nusa Dua, Bali, Indonesia. December 3rd-5th. pp. 693-698.

Yukl, G. 2007. Kepemimpinan Dalam Organisasi. PT. Indeks, Jakarta. 